
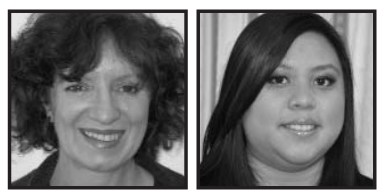

\title{
Boom. Tick. Bing! Writing Bodies In.
}

\author{
Susanne Gannon \& Diem Chi Nguyen, University of Western \\ Sydney, Australia
}

\section{ABSTRACT}

This paper describes a poetic response to the school-based practicum for beginning secondary teachers. Following their first practicum experience, in their English Method class back at the university, students pooled sensory details and memories of the week they had just spent in schools to write their own poems. The paper includes one of the poems and some thoughts about the complexity, ambivalence and embodied knowing that poetry opens up space for in reflecting on initial school experiences for beginning teachers.

For the learner and the teacher, what counts as success and failure is subject to wild vacillations and so, to revision... Mistakes, misrepresentations, confusion, conflicts, and little gifts of error are all crucial to the stuff of understanding and constructing knowledge, as are the small and large adjustments and insights we make from these events. (Britzman, 2003, p. 2)

n teacher education, "learner" and "teacher" are ambiguous and ambivalent positions. Before they begin their first practicum placement in a school, students have diligently practiced writing lesson plans and unit outlines. They've navigated complex Syllabus documents and sifted through and selected from long lists of learning outcomes. They've drafted assessment tasks and marking rubrics. They've interrogated departmental policies on diversity and inclusion. They've begun to map their developing skills against the Professional Teaching Standards for Beginning Teachers (NSW IT, 2009), practicing the language and performance of 
competence that they will need to display when they exit our course and front up for their interview with their prospective employers. Through all this preparatory work, the bodies of teachers and students are more or less elided, except as subjects of "behaviour management strategies" that teachers must have ready to deploy when teenagers misbehave. However all learning, at all stages of education, and in all sites, entails deeply embodied and unpredictable "pedagogical encounters" (Davis \& Gannon, 2009). The intellectual and professional preparation that students undergo tends to avoid the intensities, "lines of flight," and new modes of becoming that happen when people bump against each other in the flesh in the highly charged social and pedagogical spaces of schools.

Early professional education for teachers can be understood as a process of "invention" that involves an "emotional chronology" as much as an intellectual or professional one (Stronach, 2010, p. 101). It is an ongoing process, a multidimensional iterative process that never ends, and the becoming-teacher who is simultaneously a student is a subject who doesn't quite settle. Part of this process involves the "wild vacillations," "confusions" and even "little gifts of error" that are characteristic of powerful learning (Britzman, 2003, p. 2). These are most potent for students in our graduate entry Master of Teaching (Secondary) ${ }^{1}$ course during Focus Week in Week 5 of their first semester. This is a week of classroom observations in the schools to which they will return later for supervised block practicum. Students come back from Focus Week surprised by the intensity of their experiences, full of excitement and full of stories. This is when their invention as teachers really begins. Some students leave at this stage, while others become impassioned, falling in love with the profession, with the students, and with the glimpses they have of the teachers they might become. Most of their university classes in Week 6 (post Focus Week) entail reflection and theoretically informed analysis of their Focus Week experiences as their lecturers aim to bridge the perennial theory-practice gap in teacher education.

I took a different approach, interested as I am in the more ineffable, elusive aspects of teaching and learning. I'm interested too in embodied experience and how that might be represented and contested in language. In my English Method $1 \mathrm{Y}^{2}$ class, I aim to turn the students into confident creative writers and engaging teachers of writing able to inspire kids in their classes to use language to make sense of their worlds. In Week 6 this year we were playing with poetry and its interest in specificity. In one of the workshop activities, students free wrote about Focus Week in their notebooks, then filled the whiteboard with fragments of language, detailing their experiences. Their choice of red, blue, green and black markers, and their twenty-five different styles of handwriting semiotically signalled the twenty-five different experiences 
they had had. Each day and each lesson of their week on practicum refracted further into a multitude of other sensations and experiences. They filled the board with images, sensory details of sound, smell and taste, vignettes, memories, shocks of proximity to other bodies, dialogue, transitory thoughts. One student described the awkwardness of occupying a desk next to "my old Ancient History teacher (I gave her hell)" and noted "I felt weird calling her by her first name." Most dramatic, and different for them, was their inclusion in the category of "teacher" and their tentative entry into the spaces occupied by teachers-the lunches and special morning teas, the gossip and conversation, the staffroom, even Friday afternoon down at the pub. When the whiteboard with this "data" was full and when everyone had said as much as they wanted to about what was there, students took those fragments of language and each wrote a ten-line poem there and then in the class, while the material and their experiences were fresh. They incorporated aspects of poetry that we had examined elsewhere including rhythm and beat, figurative language, visual and aural patterns, experiments with line breaks, rhyme. Otherwise the instructions were simple: write a ten-line poem using any of the details on the whiteboard, keep it concrete, material, and sensory. The poems were just as likely to include details from others' experiences as from their own. In that sense, and because the students constructed these texts at least partially from the details we had pooled on the whiteboard, this exercise might be understood as an adaptation of found poetry (Butler-Kisber, 2002). It was also an attempt to demystify poetry, which for teachers as much as for their students, and more than any other genre-as poet and teacher Louise Wakeling notesis a matter of "facing down the fear" (Wakeling, 2009).

One of the poems created during that class can be found below. ${ }^{3}$ Each of the poems produced was very different in form and content, and several weeks after that class, when I heard about this special issue of the journal, after the semester was completed, I issued an open invitation to submit a poem as part of this paper. The "Boom! Tick! Bing!" of the title was a theme developed in one of the student poems not offered for final publication, reflecting the unexpected physical and metaphorical collisions of everyday life in schools, the rhythms of timetables, and the light bulb moments that convince beginning teachers to persist. Another student wrote about the ambivalence she felt as she was posted on guard for the Principal by her cigarette-smoking supervising teacher. Another student rhapsodised around the details and the warmth of the communal Easter lunch in her staff room, surprising to her as a student of Muslim heritage. Another student negotiated the complexities of being a student teacher in the school where he had been a student just four years earlier, and the continuous slippages between "teacher" and "student" that he experienced in his interactions with colleagues. Other poems took up a range of diverse issues 
they had confronted in their week in school, each profoundly different from the other despite the common discourse we had established in our discussion and in the details we had gathered on the whiteboard. Although several students expressed interest initially in submitting their poems, finally, as the frenzies of their extended practicum took over their lives, just one student chose to follow through the entire reviewing process, reworking her poem in response to editorial advice, and her poem is included below.

In the context of the class, it's important to note again that the poems were not related to any assessment task, nor were they intended for publication. Rather than an advanced exercise in poetic writing, this was an experiment in writing to capture the ambivalence of the practicum experience in a mode that offered more fluidity that the other modes of writing they had available to them. The poems provide some insight into the potential of poetry for capturing moments in the process of invention of themselves as teachers. As responses to their first practicum experiences, the poems hint at some of the moment-to-moment vacillations between success and failure, the micropolitics of schooling, the confusions and conflicts that Britzman (2003) makes reference to. As poems, the texts that follow demonstrate how poetry is "[un] afraid of sensual immersion, subjectivities, mutual constructions of meaningful relationships" and "instead of writing or talking through abstract concepts," as poets, as Brady suggests of poet-social scholars in the social sciences, they "write in and with ....what they see in themselves in relation to Others, in particular landscapes, emotional and social situations" (Brady, 2009, p. xiv).

\section{Hormone Central}

Hormones raging everywhere I walked

On my first day there, I heard teachers argue

"How about you organise morning tea?"

I smiled politely and shuffled past,

Until I reached the door of Building $\mathrm{E}$.

The temp head teacher was a tad selfish

She did not notice me when I was there.

During lunch she spoke 'bout other teachers

She tried very hard not to mention names

She whispered and said "You know that teacher ..."

I felt so awkward that I stepped outside.

"Oh my god.. What have I gotten into..." 
I wondered if this was the right career

The bitchiness shocked me to my core.

Hormones raging everywhere I walked

In the classroom the students weren't contained

One student got up and walked out the door

The teacher yelled "Get back in and sit down"

The student came back but sat on the floor

"But you told me to sit down Miss Kumar"

The students continued to misbehave

The teacher was stuck but she could not yell

All she could do now was watch, sit and wait

She turned and gave me a look of defeat

It said "There was no controlling this class"

I thought ".... I don't wanna do this anymore"

Hormones raging everywhere I walked

Lust was in the air near the toilet blocks

I was very surprised by what I saw

Students shamelessly snoggin' and caressing

Now that I am a teacher, it was uncanny

Seeing things from the other side made me sympathise

This must have been what it was like for my teachers

The playground was where they got all the goss

Listen carefully and you will know too

"Tina is hooking up with Jonathon"

I was watching my own daytime soapie,

It was live, with all the drama and so much more...

By Diem Chi Nguyen 


\section{Notes}

1. Students enter this course after completing a three-year undergraduate degree, which provides them with disciplinary knowledge. On completion of the 18month Master of Teaching (Secondary), they become certified to teach in particular curriculum areas from years 7-12 in secondary schools in New South Wales.

2. English is equivalent to English Language Arts in Canada. Students taking English $1 Y$ are those who have chosen to concentrate on English as their sole teaching specialization and therefore take "double methods" classes. There were 25 students in this class, whereas the foundation English Method $1 \mathrm{X}$ class had approximately 120 students, including this group.

3. Aiming for a real audience beyond teacher and the classroom is one of the principles of good practice in the teaching of writing that we have explored throughout the semester. However, publication entails revision and reworking of texts beyond what students trained (e.g., by school examination systems) to produce good first drafts are used to. See comments by teacher-writers on the effects that publication for wider audiences can have on "raising the bar" for student writing in schools in Gannon (2008).

\section{References}

Brady, I. (2009). Forward. In M. Prendergast, C. Leggo and P. Sameshima (Eds.). Poetic inquiry: Vibrant voices in the Social Sciences. (pp. xi-xvi) Rotterdam: Sense Publishers.

Britzman, D. (2003). Practice makes practice: $A$ critical study of learning to teach. Albany: State University of New York.

Butler-Kisber, L. (2002). Artful portrayals in qualitative inquiry: The road to found poetry and beyond. The Alberta Journal of Educational Research, XLVIII(3), 229-239.

Davies, B., \& Gannon, S. (2009). Pedagogical encounters. New York: Peter Lang.

Gannon, S. (2008). Coming to writing. English in Australia, 43(1), 33-45.
New South Wales Institute of Teachers (2009). Professional Teaching Standards. Retrieved November 19, 2010, from http://www.nswteachers.nsw.edu.au/Mai n-Professional-Teaching-Standards.html

Stronach, I. (2010). Globalizing education, educating the local: How method made us mad. London: Routledge.

Wakeling, L. (2009). Facing down the fear. In S. Gannon, M. Howie and W. Sawyer (Eds.). Charged with meaning: Reviewing English. (pp. 113-122) Putney, NSW: Phoenix Education. 


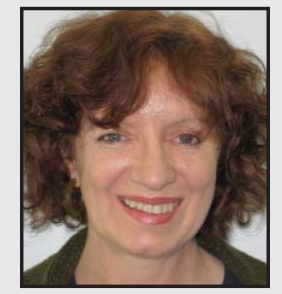

Susanne Gannon (PhD) is a Senior Lecturer in English education in the School of Education at the University of Western Sydney. She researches in diverse areas including gender and ethnicity in education and cultural studies, place pedagogies and post-structural theories. Her work on English teaching and writing pedagogies has been published in the journals English in Australia and Changing English. She has recently co-edited the books "Charged with Meaning: Reviewing English" (2009, with Mark Howie and Wayne Sawyer) and "Pedagogical Encounters" (2009, with Bronwyn Davies).

LINK TO:

http://www.uws.edu.au/education/soe/key_people/academic_staff/dr_susanne_ gannon

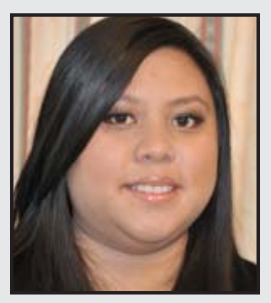

Diem Chi Nguyen is an Australian born Vietnamese. Diem Chi attended Macquarie Fields High School where she met a number of wonderful teachers. Thus, she decided she too wanted to become a teacher. After recently finishing her Bachelor of Arts she then moved on to do a Masters of Secondary Teaching. Diem Chi is currently finishing her postgraduate degree at the University of Western Sydney and is very eager to start teaching. She hopes to be as inspiring as her former teachers and make a difference in the lives of all the students she will come to teach. Diem Chi hopes to make English fun and enjoyable. 